University of Nebraska - Lincoln

DigitalCommons@University of Nebraska - Lincoln

Mammalogy Papers: University of Nebraska

State Museum

Museum, University of Nebraska State

$11-1-1969$

\title{
Notes on Pocket Gophers from Jalisco, Mexico, with Descriptions of Two New Subspecies
}

Hugh H. Genoways

University of Kansas, h.h.genoways@gmail.com

J. Knox Jones Jr.

University of Kansas

Follow this and additional works at: https://digitalcommons.unl.edu/museummammalogy

Part of the Zoology Commons

Genoways, Hugh H. and Jones, J. Knox Jr., "Notes on Pocket Gophers from Jalisco, Mexico, with Descriptions of Two New Subspecies" (1969). Mammalogy Papers: University of Nebraska State Museum. 43.

https://digitalcommons.unl.edu/museummammalogy/43

This Article is brought to you for free and open access by the Museum, University of Nebraska State at DigitalCommons@University of Nebraska - Lincoln. It has been accepted for inclusion in Mammalogy Papers: University of Nebraska State Museum by an authorized administrator of DigitalCommons@University of Nebraska Lincoln. 


\title{
NOTES ON POCKET GOPHERS FROM JALISCO, MEXICO, WITH DESCRIPTIONS OF TWO NEW SUBSPECIES
}

\author{
Hugh H. Genoways and J. Knox Jones, Jr.
}

\begin{abstract}
Systematic, distributional, and ecological data are provided for seven taxa, two described as new, of three species of the pocket gopher genus Pappogeomys in the Mexican state of Jalisco. The first Jaliscan record of Orthogeomys grandis also is reported and several instances of sympatric occurrence of pocket gophers are documented.
\end{abstract}

The varied topography and climate of the Mexican state of Jalisco and adjacent areas has resulted in a uniquely diverse and distinctive mammalian fauna in that part of western México. Pocket gophers are no exception, because no fewer than seven species, representing three genera, occur in Jalisco, more kinds than are known from any other area of comparable size.

At various times since the late 1940's, field representatives of the Museum of Natural History at The University of Kansas have collected mammals in Jalisco. The most recent collector, Percy L. Clifton, worked in the state from 1962 to 1967. Most of the pocket gophers of the genus Pappogeomys thus obtained were studied by Robert J. Russell (1968b) in the course of his revision of that genus, but those collected by Clifton late in 1966 and in 1967 either had not reached the museum or had not been processed at the time Russell's studies were completed. It is this material that forms the basis of the present report.

Remarks on eight taxa, including two newly described subspecies, of the genera Pappogeomys (as defined by Russell, 1968a, 1968b) and Orthogeomys are included herein. All measurements are in millimeters and all catalogue numbers refer to specimens in the Museum of Natural History at Kansas; age categories and cranial measurements used are those employed by Russell (1968b:587, 591). Field work that made collection of specimens possible was supported by the Kansas University Endowment Association. Laboratory phases of the work were funded in part under terms of a contract (DA-49193-MD-2215) from the U. S. Army Medical Research and Development Command. Permits for field work in México were issued by Rudolfo Hernandez Corzo and his predecessors in the Departamento de Conservación de la Fauna Silvestre, Secretaría de Agricultura y Ganadería.

Pappogeomys bulleri melanurus, new subspecies

Holotype.-Adult female, skin and skull, no. 111722 Museum of Natural History, The University of Kansas; from $7 \frac{1}{2} \mathrm{mi}$. SE Tecomate, $1500 \mathrm{ft}$, Jalisco; obtained 8 December 1966 by Percy L. Clifton, original no. 12035.

Diagnosis.-Size small for the species, both externally and cranially; coloration blackish; nasals short and acutely tapered posteriorly.

Geographic distribution.-Known only from the type locality and from $5 \mathrm{mi}$. S Purificación, Jalisco; probably occurring elsewhere along the Pacific slope of the Sierra de Perote and other coastal mountains in southwestern Jalisco (see Fig. 1). 
Measurements.-Average and extreme external measurements of four adult females (including the holotype), followed by those of an adult male, all from the type locality, are: total length 208.8 (203-215), 210; length of tail 59.0 (54-63), 52; length of hind foot 29.3 (28-31.5), 31; length of ear 5.4 (5-6), 6. Cranial measurements are given in Table 1.

Comparisons.-The area in southwestern Jalisco in which $P . b$. melanurus is known or suspected to occur lies between the ranges of two other subspecies of Pappogeomys bulleri -the nominate race in mountainous areas (up to 9000 feet) to the north and east, and $P$. b. burti of the coastal lowlands to the west. The new subspecies generally resembles $P$. b. bulleri in size (small), but differs strikingly from it in color (blackish as opposed to reddish brown in bulleri) and in that the nasals are much shorter (range 12.5 to 12.9 in four adult females of melanurus in contrast to 13.0 to 15.4 in 28 adult females of bulleri) and acutely tapered posteriorly. P. b. melanurus resembles $P$. b. burti in color, but differs from that subspecies in being much smaller, both externally and cranially. For example, of the 10 cranial measurements analyzed for both males and females of the two subspecies, no overlap was found in seven, and in the other three-palatofrontal depth, squamosal breadth, and length of maxillary toothrow-burti averages significantly larger (see Table 1 and measurements given for burti by Russell, 1968b:609). Also, in the two skins of melanurus available, the nasal patch is smaller and less distinct than in examples of burti.

Remarks.-As Russell (1968b:598) pointed out, the races of Pappogeomys bulleri are divisible into two groups on the basis of size. $P$. b. melanurus falls in the group characterized by being small, the other races of which (amecensis, bulleri, and lutulentus) all have brightly pigmented pelage. P. b. burti, a coastal subspecies of southwestern Jalisco and adjacent Colima, is a member of the group of subspecies characterized by large size, but differs from all previously described races in having relatively short, sparse pelage that is melanistic. $P . b$. melanurus evidently has paralleled $P . b$. burti in development of melanistic pelage, to which the subspecific name alludes, possibly as a response to the relatively arid, tropical environments in which both subspecies live (see Russell, 1968b: 609).

Pappogeomys bulleri melanurus likely differentiated from an ancestral stock (Russell, loc. cit.) that gave rise also to the three other small subspecies mentioned above. Probably melanurus was isolated along the lower western slopes of the coastal ranges of the Sierra Madre system, where it evolved independently of bulleri, which occurs at higher elevations in the mountains (lowest known locality for bulleri is at 1500 feet and all other localities are 3800 feet or higher).

An immature female from $5 \mathrm{mi}$. S Purificación, Jalisco, was assigned by Russell (1968b: 610 ) to burti, probably because of its blackish coloration. However, this specimen is small and has short (11.4), acutely-tapered nasals and other characters of melanurus, and clearly should be assigned to the new subspecies. On the basis of this individual, Russell (1968b: 609) suggested that "burti occurs also on the lower west-facing slopes of the Coastal Range," the habitat now known to be occupied by melanurus.

Clifton visited the type locality from 5 to 8 December 1966 and obtained four adult females, one subadult female, and one adult male. The place at which collections were made $71 / 2 \mathrm{mi}$. SE Tecomate was along a river bordered by "dense, tall, tropical deciduous forest." One specimen was trapped at the edge of a cornfield, whereas the others were obtained in forested areas. Clifton stated (field notes) that gophers were especially difficult to trap at this locality and that the six specimens obtained were collected only after a thorough search of the area.

Specimens examined (7).-71/2 mi. SE Tecomate, $1500 \mathrm{ft}$, Jalisco, 6 (109212, 111722-26); 5 mi. S Purificación, about $1500 \mathrm{ft}$, Jalisco, 1 (33453).

\section{Pappogeomys bulleri bulleri (Thomas, 1892)}

Clifton collected pocket gophers of this subspecies late in 1966 and in 1967 at seven localities in Jalisco as follows: $14 \mathrm{mi}$. NW Mascota, $6500 \mathrm{ft}, 6$ (111712-17); $2 \mathrm{mi}$. La 


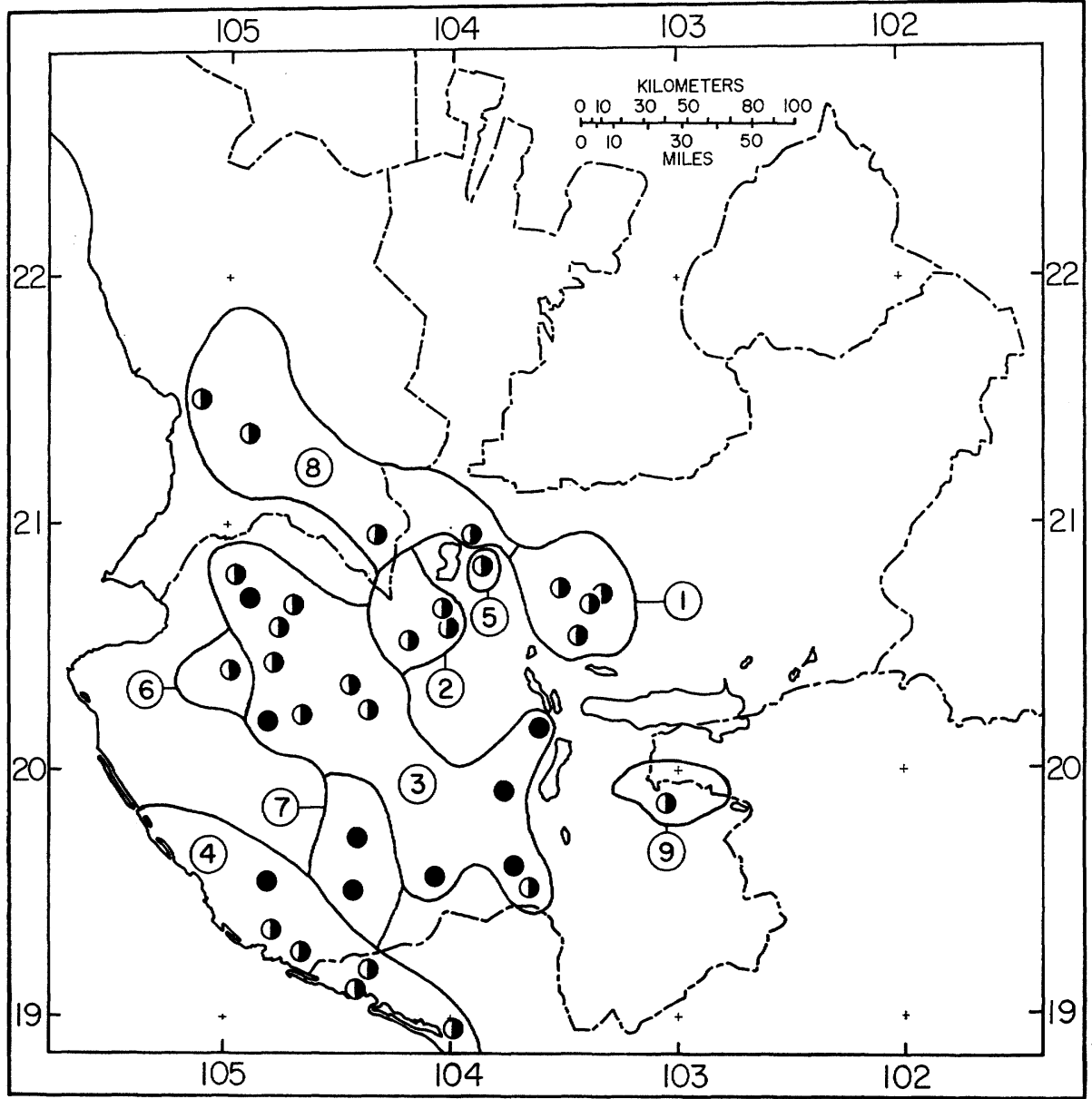

Fig. 1.-Distribution of Pappogeomys bulleri (1-8) and Pappogeomys alcorni (9). The subspecies of $P$. bulleri are as follows: $P$. b. albinasus $(1) ; P$. b. amecensis $(2) ; P$. $b$. bulleri (3); P. b. burti (4); P. b. infuscus (5); P. b. lutulentus (6); P. b. melanurus (7); $P$. b. nayaritensis (8). Solid symbols represent localities from which specimens are reported in this paper, whereas half-shaded symbols represent localities mapped by Russell (1968b:597). Region depicted is Jalisco and adjacent areas.

Cuesta, $1500 \mathrm{ft}, 4$ (111718-21); $4 \mathrm{mi}$. E Atemajac de Brizuela, $8000 \mathrm{ft}, 2$ (109204-5); 7 mi. S Tapalpa, $6800 \mathrm{ft}, 6$ (109206-11); $20 \mathrm{mi}$. SE Autlán, $7700 \mathrm{ft}, 7$ (111727-33); $4 \mathrm{mi}$. ENE Jazmín, $7700 \mathrm{ft}, 5$ (111734-38); 21/2 mi. ENE Jazmín, $6800 \mathrm{ft}, 6$ (109213-18). All but two of these localities are within, or adjacent to, the geographic range of bulleri as mapped by Russell (1968b:597). Specimens from $7 \mathrm{mi}$. S Tapalpa extend the known range of bulleri approximately 45 kilometers northwardly from Sierra Nevada de Colima and those from east of Atemajac de Brizuela provide an extension of some 80 kilometers to the east of $5 \mathrm{mi}$. NW Cuautla (see Russell, 1968b:608). Both localities are on the high mesas just to the west of the playas of Zapotlán and Sayula, which, together with associated lowlands, separate the ranges of the species Pappogeomys bulleri and Pappogeomys alcorni.

In at least one character, the extent of the enamel on the posterior wall of $M 1$, the 


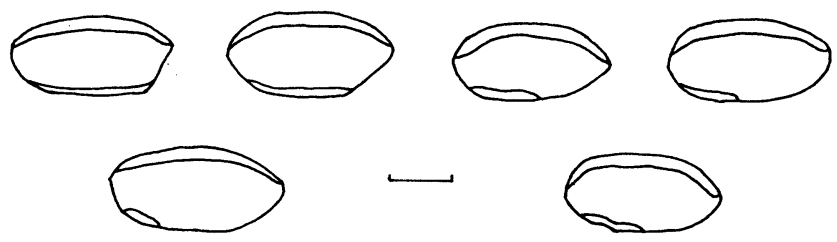

Fig. 2.-Variation in the posterior enamel plate on the first upper molar (left) in Pappogeomys bulleri bulleri and $P$. alcorni. Upper row includes (left to right) four specimens of $P$. b. bulleri from $7 \mathrm{mi}$. S Tapalpa, Jalisco: first specimen on left (KU 109211, $\hat{o}$ ) illustrates normal extent of posterior enamel plate in bulleri; the second specimen ( $\mathrm{KU}$ 109208, $q$ ) has a somewhat shortened plate; in the third and fourth (KU 109207, 9 ; 109209 , ㅇ ) specimens, the enamel plate is greatly reduced and approaches the condition found in alcorni. Lower row includes the two known specimens of Pappogeomys alcorni: left ( $\mathrm{KU} 39806$, $ᄋ$, the holotype), and right ( $\mathrm{KU} 39805$, $q$, a paratype). Scale is one millimeter long.

specimens from Atemajac and Tapalpa grade toward P. alcorni (see Fig. 2). Of the eight individuals from these two localities, two have enamel plates on the posterior wall of $\mathrm{Ml}$ that are more or less typical of bulleri, four have somewhat shorter plates labially than typical bulleri, and two have reduced plates reminiscent of the condition found in P. alcorni. Other cranial characters-broadly truncated nasals and short, rounded incisive foraminadescribed as distinctive of alcorni by Russell (1968b:616) cannot be matched in any of our specimens of bulleri, and we therefore retain alcorni as a distinct species. Additional material (only two crania and three skins of alcorni are known) is needed before variation in these characteristics can be more fully documented.

One of three adult females taken $2 \mathrm{mi}$. S La Cuesta on 4 April 1967 was pregnant. She carried a single embryo that measured 25 in crown-rump length.

\section{Pappogeomys bulleri burti Goldman, 1939}

On 30 June 1966, Clifton and Genoways trapped seven pocket gophers (107585-91) at a place $10 \mathrm{mi}$. WSW La Huerta, $1400 \mathrm{ft}$, Jalisco. On the basis of their large size (see Table 1) and blackish coloration, these specimens are assignable to $P$. b. burti, and are from a locality farther inland and higher in altitude than any specimens of that subspecies taken previously. Traps in which the gophers were caught were set in a cultivated field in which corn had been planted during the previous growing season.

\section{Pappogeomys gymnurus russelli, new subspecies}

Holotype.-Adult female, skin and skull, no. 111752 Museum of Natural History, The University of Kansas; from $12 \mathrm{mi}$. S Tolimán, $7700 \mathrm{ft}$, Jalisco; obtained 16 April 1967 by Percy L. Clifton, original no. 12567.

Diagnosis.-Smallest cranially of the known subspecies of Pappogeomys gymnurus (small size evident in both sexes, but especially females); cranium relatively short, broad across the braincase, and narrow in the squamosal region; color variable, dorsum dark brown (near Prout's Brown of Ridgway, 1912) in worn winter pelage, dark blackish brown in fresh summer pelage, paler ventrally.

Geographic distribution.-Known only from the type locality (see Fig. 3).

Measurements.-Average (and extreme) external and cranial measurements of eight adult females, followed by those of six adult males, are: total length 333.4 (326-348), 357.4 (345-371); length of tail 78.0 (72-83), 84.2 (73-90); length of hind foot $47.3(46-49)$, 48.7 (46-51); length of ear 7.3 (7-8), 7.1 (6.5-8); condylobasal length 59.6 (57.8-61.8), 63.9 (61.2-66.3); zygomatic breadth 41.6 (40.2-42.7), 47.3 (43.2-51.0); palatofrontal 
TABLE 1.-Selected cranial measurements of three subspecies of Pappogeomys bulleri.

\begin{tabular}{|c|c|c|c|c|c|c|c|c|c|c|}
\hline $\begin{array}{l}\text { Specimens } \\
\text { averaged } \\
\text { or catalogue } \\
\text { number, } \\
\text { and sex }\end{array}$ & 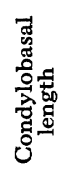 & 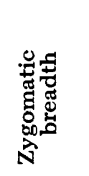 & 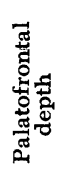 & 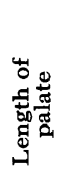 & 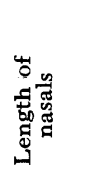 & 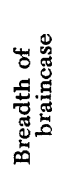 & 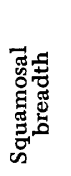 & 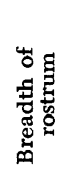 & 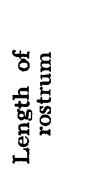 & 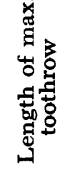 \\
\hline \multicolumn{11}{|c|}{ Pappogeomys bulleri melanurus, $71 / 2 \mathrm{mi}$. SE Tecomate, Jalisco } \\
\hline $\begin{array}{l}\text { Adult females (4) } \\
\text { Minimum }\end{array}$ & $\begin{array}{l}36.8 \\
36.2\end{array}$ & $\begin{array}{l}23.3 \\
22.9\end{array}$ & $\begin{array}{l}14.6 \\
14.4\end{array}$ & 23.7 & $\begin{array}{l}12.7 \\
12.5\end{array}$ & $\begin{array}{l}17.7 \\
17.0\end{array}$ & 21.7 & 8.3 & $\begin{array}{l}16.6 \\
16.4\end{array}$ & $\begin{array}{l}8.6 \\
8.2\end{array}$ \\
\hline Maximum & 37.8 & 23.9 & 14.8 & 24.1 & 12.9 & 18.5 & 22.2 & 8.8 & 16.9 & 9.1 \\
\hline $\begin{array}{c}\text { KU } 111726, \\
\text { adult } \sigma^{7}\end{array}$ & 37.1 & 23.8 & 14.0 & 24.0 & 13.1 & 17.9 & 22.2 & 8.4 & 16.7 & 8.4 \\
\hline \multicolumn{11}{|c|}{ Pappogeomys bulleri bulleri, Jalisco* } \\
\hline Adult females (15) & 37.7 & $23.4^{13}$ & 14.7 & 24.9 & $14.6^{14}$ & 18.3 & 21.6 & 8.2 & $17.4^{14}$ & 8.6 \\
\hline Minimum & 36.2 & 21.3 & 13.6 & 23.3 & 13.0 & 16.3 & 19.9 & 7.7 & 16.3 & 7.5 \\
\hline Maximum & 39.5 & 25.0 & 15.8 & 26.6 & 15.4 & 19.7 & 22.9 & 8.6 & 19.0 & 9.2 \\
\hline Adult males (9) & 40.1 & 25.9 & 15.5 & 26.6 & 15.5 & 19.0 & 23.4 & 8.8 & 18.8 & 9.0 \\
\hline Minimum & 37.2 & 22.2 & 14.1 & 24.8 & 13.2 & 17.5 & 20.4 & 8.1 & 17.5 & 8.3 \\
\hline Maximum & 41.9 & 28.0 & 16.6 & 28.7 & 16.7 & 20.4 & 25.0 & 9.5 & 19.7 & 10.0 \\
\hline \multicolumn{11}{|c|}{ Pappogeomys bulleri burti, $10 \mathrm{mi}$. WSW La Huerta, Jalisco } \\
\hline Adult females (4) & 41.0 & 26.9 & 15.5 & 26.9 & 14.2 & 19.2 & 24.1 & 9.5 & 18.7 & 9.8 \\
\hline Minimum & 39.6 & 25.9 & 15.1 & 25.8 & 13.6 & 19.0 & 23.3 & 8.8 & 17.4 & 9.2 \\
\hline Maximum & 42.5 & 27.9 & 15.8 & 27.9 & 14.5 & 19.5 & 25.0 & 9.9 & 19.6 & 10.5 \\
\hline $\begin{array}{c}\text { KU 107587, } \\
\text { adult } \sigma^{7}\end{array}$ & 45.3 & 30.6 & 17.6 & 30.3 & 16.8 & 21.0 & 26.5 & 10.1 & 21.4 & 10.1 \\
\hline
\end{tabular}

* Includes adults from all localities for $P$. b. bulleri reported in this paper; for additional measurements of this subspecies, see Russell (1968b:605).

Superscript numbers refer to number of specimens averaged when fewer than indicated in left-hand column.

depth 23.3 (22.2-23.9), 24.8 (24.1-26.0); length of palate $41.4(40.3-42.9), 44.5$ (42.845.7); length of nasals 20.0 (18.7-21.8), 21.8 (20.8-22.7); breadth of braincase 32.9 (31.4-33.9), 35.8 (31.9-37.7); squamosal breadth 41.6 (40.5-42.9), 46.8 (43.5-48.9); breadth of rostrum 13.7 (13.2-14.0), 15.7 (14.2-16.4); length of rostrum $25.7(24.5-27.0)$, 28.0 (26.0-30.1); length of maxillary toothrow 13.1 (12.3-14.0), 14.3 (13.5-14.7).

Comparisons.- Of the three previously recognized subspecies of the species, russelli needs to be directly compared only with Pappogeomys gymnurus gymnurus, which is known from Sierra Nevada de Colima and adjacent areas to the north and east of Tolimán. $P$. g. russelli differs from P. g. gymnurus as follows: markedly smaller cranially (see Russell, 1968b:752, for measurements of gymnurus), averaging smaller in males in all measurements except zygomatic breadth and breadth of braincase and in females in all but breadth of braincase; braincase relatively broad ( 55.2 per cent of condylobasal length in females of russelli as compared with 51.9 per cent for females of gymmurus); squamosal breadth narrow (in six of 14 adult specimens of russelli the zygomatic breadth exceeds the squamosal breadth, whereas in gymnurus the squamosal breadth usually exceeds the zygomatic breadth); tail ( 30.5 per cent of head and body length in adults of russelli as compared with 37 per cent in gymnurus) and hind foot shorter.

The other two races of the species, $P$. g. imparilis and $P$. g. tellus, differ from russelli in many of the same characteristics as does gymnurus. From these two, russelli can be distinguished by its small size, relatively broad braincase (52.3 per cent of condylobasal length in females of imparilis and 48.8 per cent in females of tellus), narrow squamosal region (squamosal breadth usually exceeds zygomatic breadth in imparilis and tellus) and shorter tail (approximately 37 per cent of head and body length in adults of both imparilis and tellus). 


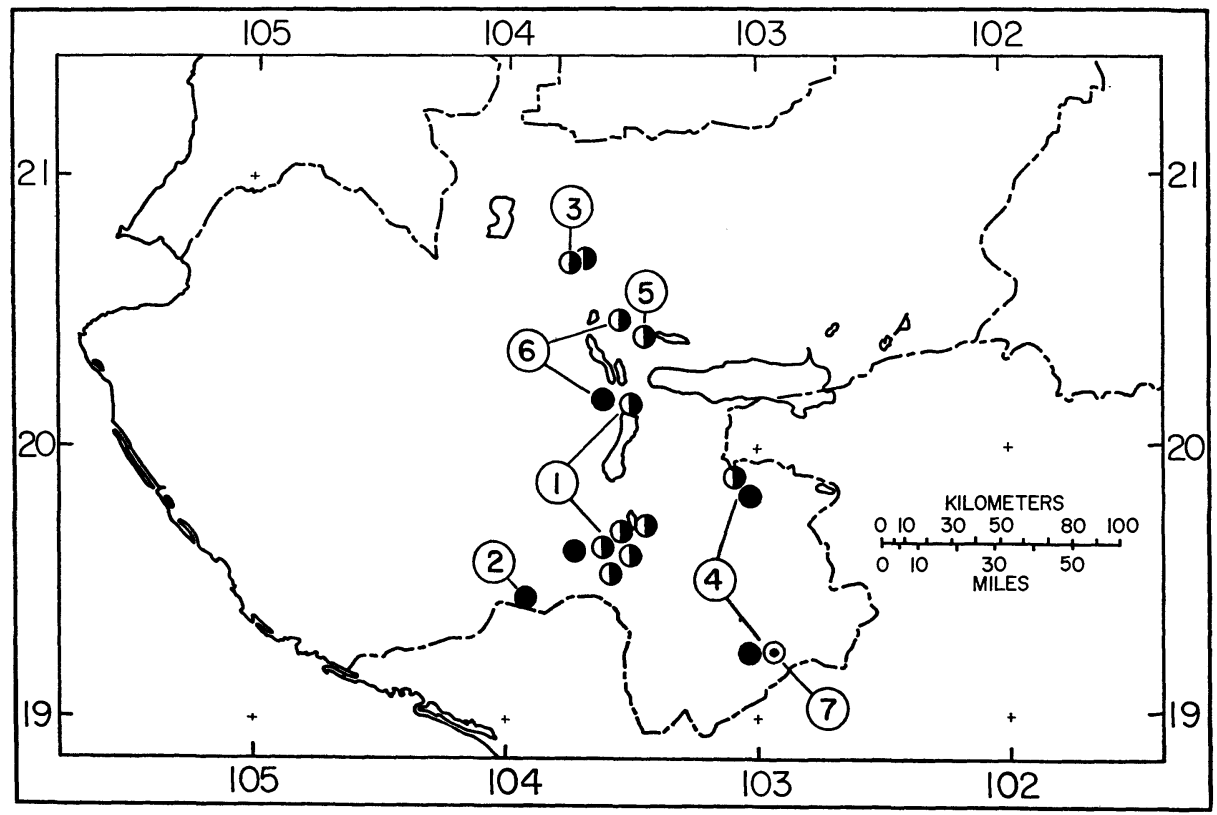

Fig. 3.-Known distribution in Jalisco of three species of pocket gophers: 1, Pappogeomys gymnurus gymnurus; 2, P. g. russelli; 3, P. g. tellus; 4, Pappogeomys tylorhinus angustirostris; 5, P.t. atratus; 6, P. t. zodius; 7, Orthogeomys grandis alleni. Map modified in part after Russell (1968b:718, 747); solid symbols and the encircled symbol represent localities from which specimens are reported in this paper, whereas half-shaded symbols represent localities mapped by Russell.

Remarks.-The new subspecies differs more from the previously described races of gymnurus than any of them differ from each other. Considering this situation, Russell (1968b:750) wrote as follows: "The species approaches morphological homogeneity; differences between the subspecies, especially in external and cranial features, are slight. The principal distinction between the several subspecies is in coloration." This statement does not hold true for russelli, however, which is distinctly smaller than the other subspecies and in at least one characteristic, breadth across the squamosals, approaches Pappogeomys fumosus of adjacent Colima. One of the key characteristics used by Russell (1968b:594) to distinguish fumosus from gymnurus was that the squamosal breadth is less than the zygomatic breadth in fumosus as opposed to usually greater than the zygomatic breadth in gymnurus. In 42.8 per cent of the specimens of $P$. g. russelli the zygomatic breadth is greater than the squamosal breadth. Also, russelli is the smallest race of gymnurus and in this feature also grades toward fumosus; the latter, however, is considerably smaller than russelli. Additional material from southwestern Jalisco and adjacent Colima is needed to clarify the relationship between these two species.

Of our eight April-taken skins of russelli, three are dark blackish brown dorsally and appear to have completed molt, or nearly so, to summer pelage. Four are dark brown dorsally, but all were molting, the brownish winter pelage being replaced by dark blackishbrown hairs. The eighth individual, an adult male, is pale yellowish tan, excepting for a few black-tipped hairs, and also was molting (the new pelage is slightly paler and somewhat shorter than the old). All specimens except the one last mentioned are paler ventrally than dorsally. Pelage on the venter of those individuals in advanced stages of molt 
is less ochraceous (more grayish) in color than in those on which worn winter pelage remained, and the pelage is less dense.

The area 12 miles south of Tolimán is forested with alder, some oak, and a few scattered pines, and supports also low brush. Bunch grass predominated in areas that had been cleared of trees. Clifton stated (field notes) that the soil in this area was pliable and that excavation of burrows was easily accomplished except in areas of outcropping rock. Numerous sinks had been formed in the rocks and many gopher mounds were found in soil at the bottoms and on the slopes of sinks.

We take great pleasure in naming this new subspecies for Robert J. Russell, in recognition of his recent revision of the genus Pappogeomys.

Specimens examined (15).-12 mi. S Tolimán, $7700 \mathrm{ft}$, Jalisco, 15 (111741-55).

\section{Pappogeomys gymnurus gymnurus (Merriam, 1892)}

This subspecies occurs in the valleys and low basins of south-central Jalisco, southwestward to Sierra Nevada de Colima (Russell, 1968b:751-754). The first specimens from the northwest slope of Nevada de Colima were obtained in the period 19 to 21 March 1966, when three adult females, two subadult females, and two subadult males (109220-26) were trapped at a place $2 \frac{1}{2} \mathrm{mi}$. ENE Jazmín, $6800 \mathrm{ft}$. On 8 February 1967, a subadult female (111740) was taken $4 \mathrm{mi}$. ENE Jazmín, $7700 \mathrm{ft}$. Considering sex and age, all of these specimens are relatively large and the four available skins are in the rusty color phase; therefore, they resemble topotypes of gymnurus and other specimens from lower altitudes to the east of Nevada de Colima more than they do samples from higher on the slope of the mountain (see Russell, loc. cit.). The three adult females have zygomatic breadths of $45.8,46.4$, and 46.7 , exceeding that measurement in all previously reported females of this subspecies.

Pine-oak forest prevailed in the area $2 \frac{1}{2} \mathrm{mi}$. ENE Jazmín along with some scattered alder. Some places had been logged in the past and were planted to corn. In addition to Pappogeomys gymnurus, Clifton also obtained P. bulleri at this locality and, in fact, stated in his notes that the two kinds were trapped within 30 feet of each other. At the locality $4 \mathrm{mi}$. ENE Jazmín the forest also was pine-oak, but predominately pine. Traps were set around the edge of an old cornfield; at this place, too, Pappogeomys bulleri was taken along with $P$. gymnurus.

\section{Pappogeomys tylorhinus angustirostris (Merriam, 1903)}

Between 17 and 19 January 1967, Clifton obtained three P. t. angustirostris at Jilotlán de los Dolores, $2400 \mathrm{ft}$, Jalisco (111756-58). From there he moved to a place $8 \mathrm{mi}$. E Jilotlán de los Dolores, $2000 \mathrm{ft}$, where in the period 20 to 23 January three additional specimens (111759-61) were trapped. In early March, Clifton returned to this same locality and obtained still another individual (111762). These specimens are from approximately 68 kilometers to the south of the nearest known locality for the subspecies ( $3 \mathrm{mi}$. WSW Mazamitla) and about 85 kilometers to the southeast of the nearest locality in Michoacán, Nuevo San Juan (= Los Conejos), where it is known (see Fig. 3). The specimens agree with all measurements given by Russell (1968b:728) for typical angustirostris, excepting in the length of the maxillary toothrow. The toothrows of three adult females and an adult male measured, respectively, 12.8, 12.8, 13.7, and 13.8, and are longer than in typical specimens. All of our gophers are melanistic.

At Jilotlán de los Dolores, Clifton noted that most of the original tropical deciduous forest had been cleared and planted to corn, bananas, and mangos. Gophers were trapped in a banana plantation at the west edge of town. The situation in which gophers were trapped $8 \mathrm{mi}$. E Jilotlán de los Dolores is discussed in the account of Orthogeomys grandis alleni.

One additional specimen of this subspecies, a subadult male (109203), was obtained 6 mi. S Mazamitla on 28 September 1966. 


\section{Pappogeomys tylorhinus zodius (Russell, 1959)}

A young adult male (109219) from $4 \mathrm{mi}$. E Atemajac de Brizuela, $8000 \mathrm{ft}$, provides the second known locality of record for this subspecies. The gopher was trapped on the Mesa de Tapalpa at a place approximately 35 kilometers south of the type locality and some 3500 feet higher in elevation. We assign our one specimen to zodius because it agrees with the type series in color and the squamosal breadth is 64.2 per cent of the condylobasal length, less than in other subspecies of $P$. tylorhinus.

The area where our specimen was trapped on the Mesa de Tapalpa was forested mostly by pine but also by a few oaks. Pappogeomys bulleri bulleri was taken at the same place, one of the few locations where large and small species of Pappogeomys occur sympatrically.

\section{Orthogeomys grandis alleni Nelson and Goldman, 1930}

An adult female (111739) taken on 16 March 1967 at a place $8 \mathrm{mi}$. E Jilotlán de los Dolores, $2000 \mathrm{ft}$, is the first specimen of the genus to be reported from Jalisco (see Fig. 3). This female and three previously unreported specimens (62521-23) of Orthogeomys grandis felipensis from $1 \mathrm{mi}$. SSW Tilapa, $3700 \mathrm{ft}$, Puebla, represent the northernmost known records of the species. We tentatively assign our specimen to the subspecies alleni because it generally agrees with the external and cranial measurements given for that subspecies in the original description (Nelson and Goldman, 1930:157). In only one cranial characteristic, breadth of the interorbital region, does the Jaliscan specimen differ markedly from the holotype of alleni (interorbital breadth 16.8 in KU 111739 as compared with 10.3 in the holotype). Hall and Kelson (1959:458) reported a specimen of Orthogeomys from 1/2 mi. E La Mira, $300 \mathrm{ft}$, Michoacán (39807), under the name O. g. guerrerensis. However, this specimen, an adult female, is much larger than any known specimens of guerrerensis (Nelson and Goldman, 1930:159) and in our opinion also is best assigned to alleni. This results, then, in restriction of the geographic range of $O$. g. guerrerensis to the Balsas Basin, whereas O. g. alleni evidently occurs in the arid coastal lowlands and adjacent areas of Oaxaca, Guerrero, Michoacán, and southeastern Jalisco. Selected external and cranial measurements for the specimens from Jalisco and Michoacán are, respectively, as follows: total length 393,372 ; length of tail 110, 104; length of hind foot 55 , 53; condylobasal length $69.7,65.9$; zygomatic breadth $45.5,40.8$; squamosal breadth 42.3, 40.8; interorbital constriction 16.8, 13.5; length of nasals 27.0, 22.5; length of maxillary toothrow $14.9,14.0$.

The place $8 \mathrm{mi}$. E of Jilotlán de los Dolores appears to be the first locality at which the genera Orthogeomys and Pappogeomys have been reported as occurring sympatrically. There, orchards of mangos, banana plantations, and cornfields were located along the Río Apaste; low tropical deciduous forest grew on hillsides adjacent to the river valley. It was in traps set on these low forested hillsides that Clifton obtained the two genera.

\section{Literature Cited}

Hall, E. R., AND K. R. Kelson. 1959. The mammals of North America. Ronald Press, New York, 1: xxx + 1-546 + 79 .

Nelson, E. W., AND E. A. Goldman. 1930. The pocket gophers of the genus Orthogeomys. J. Mamm., 11: 155-159.

Ridgway, R. 1912. Color standards and color nomenclature. Privately published, Washington, D. C., iii +43 pp.

Russell, R. J. 1968a. Evolution and classification of the pocket gophers of subfamily Geomyinae. Univ. Kansas Publ., Mus. Nat. Hist., 16: 473-579.

1968b. Revision of pocket gophers of the genus Pappogeomys. Univ. Kansas Publ., Mus. Nat. Hist., 16: 581-776.

Museum of Natural History, The University of Kansas, Lawrence, 66044. Accepted 28 May 1969. 